\title{
CRITICAL LITERATURE REVIEW IN TEFL RESEARCH: TOWARDS INTERDISCIPLINARY STUDY
}

\author{
Wakhid Nashruddin \\ IAIN Syekh Nurjati Cirebon \\ wahid1n@yahoo.co.id \\ Hanna Azmi Zakiyyah Mustaqimah \\ IAIN Syekh Nurjati Cirebon \\ hanaazmizakiyyah@gmail.com
}

\begin{abstract}
The fact that English as a second language is perceived to be failed has been a source of criticism for stagnating research in English Language Teaching (ELT). One explanation is that the essence of human learning language has not been taken into account. Furthermore, the tendency that a single model of theory applications narrow the subject of research in ELT, using linguistic theories to develop language capacity. Brain study, such as neuroscience, seems to be neglected for considerations that it is irrelevant to language learning. This article identifies the possibilities of using a new approach for developing the area of TEFL. As this is a literature review, the report is to argue that critical literature review may be useful for initial stage studies, crossing the boundaries of what is called a relevant or irrelevant field, and to identify possible steps in doing a critical literature review.
\end{abstract}

Keywords: critical literature review, EFL learning research, interdisciplinary study

\section{BACKGROUND}

Critics to the stagnation of research in the area of teaching and learning English as a second language has emerged from time to time, criticizing that ESL has worked towards the learning of language abilities as learning the language and forget to include how the thinking as the primary language use. As such, the critics informed that the learning process, involving the complicated process of language processing in the brain, considering different kinds of influencing factors, such as social and the context of language use, has been neglected. Bumela (2020, p. 4), for instance, illustrates how different kinds of second language learning practice are based on Systemic-Functional Linguistics, descriptive linguistics, and on ready-made tools computer software. The research approach normally focuses on qualitative, quantitative, or mixed-research, 
without acknowledging what is new from research, that the novelty of the research is also crucial in determining the development of knowledge, making research incompatible with the $21^{\text {st }}$-century spirit of developing new knowledge.

The 21st-century emerges, and countries all over the world respond to it by developing a qualification framework for standardizing educational outcomes. The Government of the Republic of Indonesia, for example, has developed the IQF (Indonesian Qualification Framework), a quality education standard to fulfill the demand of an increasingly mobile and globalized higher education sector, and to strengthen Indonesia's competitive position and make the country more responsive to the global market (A. B. Lian, \& Pertiwi, 2017, p. 2). The largely a theoretical approach to addressing the requirements of the new higher education reforms reveals a need for change (Nashruddin, 2019). However, the current study shows that, in the area of ELT, research culture and practices of pedagogy in ELTE programs did not contribute much to the building of a 21st century model of ELTE programs in Indonesia (Nashruddin, 2019). This leads to "boring" research practices, doing research on the same theoretical basis again and again.

The niche of research can be seen from the absence of such research, whether in the form of its approach, design, data collection technique, or data analysis techniques. However, rarely addressed is the new connection of research with different kinds of related field or interdisciplinary study. Zang (2017), for example, offer critical literature review for evaluating English language textbook, but the point of view was just SFL. There is nothing wrong with SFL, but one single lens to view the quality of an English textbook provides no direction to a new possibility or alternative evaluation parameters. Using one single lens make the evaluation, not objective, as the standard is only one standard. In the end, Zhang offers nothing except SFL to "optimize the evaluation of English language teaching textbook content" (p. 78).

Innovation in research is needed in such a way to find a new perspective in the area of ELT. The demands for changes and creativity in this field should promote and endorse innovative and critical approaches to research (e.g., Thomas, 2007, as cited in Nashruddin, 2019). To play with ideas and strategies is better than unquestioningly following models from the past, which have been built to adapt to the needs of the past (Nashruddin, 2019). Doing a literature review is a possible way to initiate the development of new knowledge (Jesson, Matheson, Lacey, 2011, p. 16). Here, a critical literature review offers something that research needs, a strong basis based on tested theories for developing experimentation or knowledge exploration.

The ways humans learn, for example, not only use cognitive ability, such as thinking, but also other ways, such as embodiment. Human bodies also absorb knowledge, and this can be integrated into ELT research (Lian, 2017). Aesthetic, for example, can contribute to language learning, as has been shown by Lian, Bordnarchuk, Lian, \& Napiza (2017). Opening the possibility of integrating findings from research from the different fields is very rare in the ELT field, for example, Neuroscience.

The critical literature review is so important that it becomes a unit for teaching at different universities in many countries (e.g., at Southern Cross University, Australia). This unit facilitates the development of a literature review to identify and explore a specific research problem, and the students are mentored in skills and understanding, including literature searching and selection; conceptual framework development; theoretical framework development; analysis, synthesis, and evaluation of literature; and academic style and structure (www.scu.edu.au). 


\section{Critique in ELT research}

Many research publications attempt to reveal how and why some methods and tools have a significant impact on English language lives. In other words, these kinds of framing show that the teachers know what to teach and how, less than why (Lian, 2019, p. 442). In other words, the educators have to consider "what," "how," and "why" or, put simply, these are one package to develop students learning experience (England, 2016, p. 5). In addition, Marzano (as cited in Campbell, 2016, p. 1) notes that most educators and researchers rely heavily on teacher-centered instruction that emphasizes lecture, practice, and review. This research and teaching culture in education as unadventurous and obsessed with "what-is" and "what has been," thus "collectively excluding the raw light of new ideas" (Thomas, 2007 as cited in Lian, 2019, p. 442). A limited field of related knowledge that usually appeared and discussed in ELT research seems to demonstrate "unchanging" research. Logically, Thomas' critique clearly expressed the need for creativity, imagination, and expansive thinking of the educational system (Lian, 2019 , p. 44). Zhang's study (2017), as abovementioned in the previous section, clearly exemplifies this situation.

\section{The changing world of English language research}

The development of technology possibly influences the way how we look at English language teaching and learning perspective. In other words, rapid advancement in information and communication technology (ICT) is continuously changing the landscape of academic, professional, and personal lives (Barrot, 2018, p. 1). The use of technology as supporting equipment is often used in English language teaching and learning, "technology embed in everyday discourse and activity" (Chapelle, 2003, p. 1). In today's information age, great sources of literature in electronic databases (i.e., internet and technology) have a critical point to see a new perspective of the English language in the 21 st-century demand.

The technology used to attempt to bring it back into the foreground to explore its implications for language teachers and researchers (Buce, \& Hogan, as cited in Chapelle, 2003, p. 2). Therefore, there is no excuse not to expand knowledge regarding the English language to create a new innovation. Along with English language teaching development, twenty-first-century beliefs come along with some essential skills necessary for people to live in the fast-paced century. The important skills categorized as describing "ways of thinking, ways of working, tools for working, and skills for living in the world" (England, 2016, p. 4). Therefore, today's educational policy (e.g., in Indonesia) embed $21^{\text {st }}$ beliefs as a critical concern for the practitioners, policymakers, teachers, researchers, etc. This is a time for a new model-one that is dedicated to preparing learners for a place in the fast-changing world (Alcock, 2016, p. 52). 


\section{The critical approach to knowledge construction}

Critical thinking requires the development of a wide range of skills, but these are skills for life, and hence it is worth investing time to learn them. Many students find developing critical thinking challenging because their education so far has been based on hearing, reading, learning, and repeating in examinations (Jesson, Matheson, Lacey, 2011, p. 16). Educators are important in the process of students' critical thinking development. However, Professors' and teachers' skills are valued but rarely questioned (p. 16). The largely a theoretical approach to addressing the requirements of the new higher education reforms reveals a need for a change in what institutions, and ELTE departments specifically, value as disciplinary research. Investment in research is needed, where researchers adopt a critical approach to the subject areas that they teach (Nashruddin, 2019).

Critical review, in many cases, just use resources from the main field and did not have a look from different fields or doing an interdisciplinary approach. Critics argue that it is too transparent and versatile to design and process for a conventional study, with one main difference is that there is no need to include a process report (Jesson, Matheson, Lacey, 2011, p. 24). However, to make a critical review more trustworthy, it is important to include a process report, the intent of the review, how to find the sources, what is included, what is excluded, and why exclusion happens.

\section{Critical literature review}

Critical literature review is a method employing a systematic review design. "Critical literature reviews provide current opinions of key authors in their subject area, show up-to-date conceptual understanding, evaluate the strengths and weaknesses of previous work, and allow others to follow up on the work you cite, use correct and detailed references" (Jesson, \& Laccey, 2006, p. 145). In addition, the primary purpose of a critical literature review is to critically evaluate and improve the existing state of knowledge on the topic under review as a means of identifying gaps in information that a new study may attempt to resolve (Carnwell \& Daly, 2001, p. 57). In other words, this leads to the development and advancement of the theory, closes research gaps, and identifies areas where previous research has been lacking (Al-Emran, Mezhuyev, \& Kamaludin, 2018, p. 4).

Writing a literature review is a dynamic process where different parts of the review are interconnected and inform each other. Although the writing of a review is seen as a step-by-step activity, this method is not linear in fact (Efron \& Ravid, 2019, p. vi). In fact, it is complex to write a literature review, and various sections of the review are interconnected and inform each other (p. vi). It is very possible to skip a step between the suggested or go back and forth among the steps. The critical literature review is more than that.

A critical literature review can only be completed by focusing on a judgment structure. A critical literature review, unlike other types of literature reviews, cannot be carried out by writing notes and using bibliographic referencing software search engines, but by relying on a decision structure that analyses the theoretical context of the articles, their conclusions, and one that provides the paper with a logical structure (GheondeaEladi, 2015, p. 167).

Some of the best advances in knowledge come from bringing two or more separate fields of study together. In the content choice of literature review, there are 
topics need to be more experimental, and maybe looking at the work of various academic disciplines can be useful since some of the most remarkable developments in science come from putting together two or more different fields of research to build a new viewpoint (Jesson, Matheson, Lacey, 2011, p. 20). The research question will guide the literature search leading into the relevant literature (Jesson, Matheson, Lacey, 2011, p. 18). The process of the critical literature review can be as follow (Jesson, Matheson, Lacey, 2011, p. 20):

1. Formulate a draft research question.

2. Search, scan, for information, using keywords.

3. Skim, scan, read, reflect, and search some more, defining key concepts.

4. Obtain articles and read some more.

5. Reassess your question.

6. Formulate the final research question for analysis.

All information in all journals can be included, regardless of impact status. In a lower rating journal, there could be an equally good paper that could not get past strict submission requirements; as a result, some writers purposely prefer to publish in lessrated journals so that their work can be published soon (Jesson, Matheson, Lacey, 2011, p. 23). The search strategy and the requirements for inclusion in the analysis are essential to data quality, so it is important to document each stage of the process (Jesson, Matheson, Lacey, 2011, p. 30).

\section{METHOD}

This is a qualitative analysis employing a literature review. The steps of doing the review are as follow (adapted from Efron \& Ravid, 2019, p. vi):

1. Choosing a review topic and formulating a research question

The process is begun by identifying the topic of research, narrowing it down by sharpening its focus, followed by the formulation research question (Efron \& Ravid, 2019 , p. 38) is necessary for undertaking a literature review. Three points of interest were categorized: Personal interest may emerge from everyday life; Practical interests may arise from issues of policy, programmatic changes, opportunities, or problems encountered in practice; and Intellectual interests maybe motivated by a desire to understand in-depth the theoretical perspective (Efron \& Ravid, 2019, p. 40). In this article, the topic of the research is understanding critical review, focusing on opening possibilities of integrating different fields into ELT research.

2. Locating and organizing research sources

Rich sources or literature (e.g., books, journals, articles, conferences, papers) possibly exist either located on electronic databases or library with the quality and trustworthiness of the information found online have to be established and confirmed (Efron, \& Ravid, 2019, p. 59). The need for having keywords are considerable for choosing and finding literature related to topic interest and research question. Most importantly, a research question may help the researcher to decide a keyword. Deciding keywords for searching related sources is possibly use the 
systematic list of a synonym (e.g., thesaurus) (Efron, \& Ravid, 2019, p. 63). In this article, the main keywords are critical literature review, EFL learning research, and interdisciplinary study.

3. Selecting, analyzing, and keeping notes of sources

The process of analyzing the literature requires the reader and researcher to Organize a reading list of reviews. This means extracting only relevant information from the selected sources in order to create your own original review of the literature (Blumberg, Cooper, \& Schindler, 2008, as cited in Efron, \& Ravid, 2019, p. 74). Creating criteria for literature selection may useful for the discussion issue targeted specific review. In this study, the inclusion and exclusion criteria are not explicitly demonstrated (Efron, \& Ravid, 2019, p. 63).

4. Evaluating research articles

Once the researchers have followed some initial steps of literature review, it turns to critically evaluate the literature that has been addressed to your research area. Writing a literature review is important to adopt a critical stance toward the sources reviewed and acknowledged their weaknesses, as well as their strengths (Efron, \& Ravid, 2019, p. 63). In addition, a critical literature review may involve critically evaluate the title, abstract, introduction, literature review, and research question (Efron, \& Ravid, 2019, p. 63). In this current study, all possible resources are examined with the limit to find an example of a critical literature review that can be replicated.

5. Structuring and organizing the literature review

In this process, the researcher needs to include the synthesis matrix strategy. This strategy involves an interactive process where the researcher examines their analysis of individual sources and groups them together in a grid to discern patterns and themes in the literature (Whittemore \& knafl, 2005 as cited in Efron, \& Ravid, 2019, p. 123). In this article, the structures are as in the finding and discussion section.

6. Developing arguments and supporting claims

"The argument should not merely echo the ideas of authors whose writings you have reviewed, but rather advance or expand what is known and present it from your own unique perspective" (Efron, \& Ravid, 2019, p. 156). However, the researcher's idea or argument is less credible if no supporting evidence or claims from theorists, scholars, policy, etc. The quality of evidence requires some critical points; accurate, precise, authoritative, representative, current, and relevant (Booth, 2008; Machi \& McEvoy, 2012 as cited in Efron, \& Ravid, 2019, p. 160). In this article, the arguments are built inherently in the finding and discussion section.

7. Synthesizing and interpreting the literature

Synthesizing involve the process of unifying the separates elements from each study, into logical points to produce a coherent argument, theory, and conclusion (Pope, 2017, as cited in Efron, \& Ravid, 2019, p. 177). This step can be started by grouping the sources, comparing, and contrasting sources (Efron, \& Ravid, 2019, p. 160) based on related research area and purpose. In this study, the process is not shown for the limit of the research article. 


\section{Putting it all together}

Those processes should critically involved in creating a good and comprehensive literature review. Finally, in this study, all arguments are wrapped up and rechecked for consistency through the text.

\section{FINDINGS AND DISCUSSION}

\section{Rationale of Critical Literature Review Research Method and Design}

In regard to the critical literature review, systematic designs were involved in defining a critical literature review. In other words, while critically evaluate the literature, the researcher needs a design in which promotes a detailed and well-organized design. Conceptual systematic review emerges a new design to review the literature critically. In addition, systematic design tend to use a more rigorous and well-defined approach to reviewing the literature in a specific subject area and systematic reviews are used to answer well-focused questions about practice (Cronin et al., 2008, p. 39). However, this design is different from traditional or narrative review. In traditional review, the criteria for specific sources of review do not appear to the reader (Cronin et al., 2008, p. 39). In contrast to the traditional review, systematic reviews demonstrate the specific and well-defined criteria (Cronin et al., 2008, p. 39) in order to help the researcher critically evaluate the literature. Examples of this are set inclusion or exclusion criteria, quality of the literature, and time frame (Carnwell \& Daly, 2001, p. 59).

\section{Possible strategy in looking for data sources}

The Source of data is the data of research which the data is acquired. Library research is used in getting the sources of the data. Library research involves the step-bystep process used to gather information in order to write a paper, create a presentation, or complete a project (Elmer E. Rasmuson Library, n.d, "Library research process," para. 1). The data was taken from some literature (journals) related to the implementation of CALL (Computer-Assisted Language Learning). A literature search was conducted to get the sources of the data. In addition, a literature search offers a systematic and wellorganized search of already published data to identify the depth of reasonable references on a particular issue (Grewal, Kataria, \& Ira, 2016, p. 635).

Nowadays, the emergence of the internet assists the researcher to find the sources from specific databases. Therefore, literature searches were undertaken by using computers and electronic databases. In contrast to the past, visiting the library is a common way to find out and explore the literature; books, journals, articles, etc. In addition, computer databases offer access to vast quantities of information, which can be retrieved more easily and quickly than using a manual search (Younger cited in Grewal et al., 2016, p. 636). Numerous possible database available for the literature: 
Table 1. Electronic database and search engine for literature collection

\begin{tabular}{|c|c|}
\hline Resources & Web Addresses \\
\hline $\begin{array}{l}\text { Search Engine } \\
\text { Google } \\
\text { Google Scholar }\end{array}$ & $\begin{array}{l}\text { http://www.google.com } \\
\text { http://www.scholar.google.com }\end{array}$ \\
\hline $\begin{array}{l}\text { International electronic source of } \\
\text { database } \\
\text { ERIC } \\
\text { Taylor \& Francis } \\
\text { Research Gate } \\
\text { Academia } \\
\text { SAGE Knowledge } \\
\text { Science Direct }\end{array}$ & $\begin{array}{l}\text { https://www.eric.ed.gov } \\
\text { https://www.tandfonline.com/ } \\
\text { https://www.researchgate.net/ } \\
\text { https://www.academia.edu } \\
\text { https://sk.sagepub.com } \\
\text { https://www.sciencedirect.com }\end{array}$ \\
\hline $\begin{array}{l}\text { Indonesian electronic source of } \\
\text { database } \\
\text { Perpustakaan Nasional (Perpusnas) } \\
\text { Indonesian Publication Index (IPI) } \\
\text { Science and Technology Index } \\
\text { (SINTA) }\end{array}$ & $\begin{array}{l}\text { http://e-resources.perpusnas.go.id } \\
\text { http://id.portalgaruda.org/ } \\
\text { http://sinta.ristekbrin.go.id/ }\end{array}$ \\
\hline
\end{tabular}

Rich data or literature from electronic databases will be hard to find in certain journals and articles. Relevant data (e.g., journals and articles) are what the researcher needs to consider. "the more specific the topic or question being searched is, the more focused the result will be" (Newell, \& Burnard, 2006, cited in Cronin, Ryan, \& Coughlan, 2008, p. 40). Therefore, the researcher needs to use keywords to find out the appropriate journals and articles. Keyword searches are the most widely known way to identify literature (Cronin, et al., 2008, p. 40). However, there are some difficulties in obtaining journals and articles if the researcher focused on limited keywords.

In other words, "Boolean operator" is necessary to be involved as a strategy to find out the literature. Boolean operator refers to a strategy of combining keywords (Cronin, Ryan, \& Coughlan, 2008, p. 40). The strategy encompasses three keywords AND, OR, and NOT. "AND" refers to find out articles that include all the identified keywords (e.g., CALL and $21^{\text {st }}$ century), OR refers to find out articles that include any of the identified keywords (CALL or Web enhance language learning), and NOT refers to exclude articles that contain this specific keyword (e.g., CALL Indonesia not international) (Cronin et al., 2008, p. 40). In regard to this, the researcher collects numerous journals and articles from databases, which then will be chosen based on the inclusion and exclusion that will be explained in the next point. Most importantly, 
searching the literature were effectively start from the current research to find out the current and new perspective of the necessary field of literature (Galvan, 2014, p. 25), but with more open thinking to cross different fields and see what can be learnt from those fields.

\section{Possible Data Collection Technique}

Initial screening was used by the researcher to get the data. A Sage research method paper (Lavarakas, 2008) describes the initial screening as the initial process by which elements are evaluated to determine whether they are eligible for research. This process lies in abstracts identification, in which the abstract of journals and articles were scrutinized to ensure that they fulfilled the criteria. In the case of defining criteria, the researcher may attempt to narrow the criteria, which is facilitated by inclusion and exclusion. Inclusion and exclusion criteria promote researchers with a clear decisionmaking framework for researchers in regard to the relevance of works included (Carnwell \& Daly, 2001, p. 59). Inclusion refers to something that should exist in the journals. In contrast, exclusion refers to the thing that is out of the content of the journal. In other words, the articles, journals, and books that will be critically analyzed should meet the inclusion and exclusion criteria.

Table 2. An example of literature selection

\section{Inclusion}

a. Should be published between 2018 and 2020.

b. Teaching practice in CALL research: Indonesia

c. Should involve learning and teaching practice towards CALL.

d. Journal indexed nationally or internationally

e. CALL research in English language learning

\section{Exclusion}

a. Journal which not involve a learning and teaching process toward CALL

b. Not indexed nationally (SINTA, IPI) or internationally (Scopus)

c. General CALL research (not English language learning)

In regard to the relevance of journals in terms of content (i.e., inclusion and exclusion), the researcher considers several technical criteria to select a journal, such as indexing status, impact factor score (journal or author), and journal operation (Suiter, \& Sarli, 2019, 462). Journal indexing status becomes a norm to determine the quality of the journal. In other words, a journal that is indexed by a national or international index system (e.g., SINTA (Indonesia indexing database), SCOPUS, and Google Scholar) have to go through a vetting process to be included in reputable bibliographic databases ("What are journal indexes?"). In regard to this, the impact of the factor score of a journal needs to be considered. The impact factor score calculates the number of 
citations of the journal (Suiter, \& Sarli, 2019, p. 464). Other than that, journals are usually related to DOI or ISSN. Digital Object Identifier (DOI) is assigned to articles, or an International Standard Serial Number (ISSN) is assigned to the journal; those include the archival practice of article (Suiter, \& Sarli, 2019, 464).

Table 3. An example of specific literature selection criteria

\begin{tabular}{lll}
\hline Indexing status & $:$ SINTA or \\
& SCOPUS or \\
& Google Scholar \\
Impact Factor Score $\quad:$ & SINTA : S4 (minimum) \\
& SCOPUS/Scimago journal rank: Q3 (minimum) \\
& Google Scholar: H-index 4 (minimum) \\
Journal Operation & $:$ DOI or, \\
& ISSN
\end{tabular}

For example, in analyzing research literature, Mustaqimah (2020) include the review as covering the literature for the period 2018-2020 and 3 journals from reputable journal databases. In addition, the researcher uses the thesis as data to review. The criteria of the thesis refer to the inclusion and exclusion of journals and articles, except indexing. This was to reflect evidence supporting the position of research and claims relating to the CALL implementation/practice in the classroom.

The rationale of A Sample Research System

\section{Planning the Review}

Step 1: Selecting the keywords and database

Step 2: Searching the database such as ERIC, Academia, Research

\section{Conducting the Review}

Step 3: Reviewing the abstract.

Step 4: Sorting the journal, article, and thesis.

Step 5: Conducting a detailed review of Journals.

Figure 1. Steps of doing a critical literature review

\section{An example of data analysis technique}

The following example of data analysis is used by Mustaqimah (2020) in a study about developing criteria for Technologically Enhanced English Language Learning (TEELL). In conducting the data analysis, seven references were identified and reviewed. Clustering and synthesizing processes were involved to get a comprehensive 
criterion of 21 st-century TEELL. The process of clustering was used to clearly see different perspectives from different references. In addition, table and checklist forms were used to facilitate the clustering process.

Table 4. Clustering process (Mustaqimah, 2020)

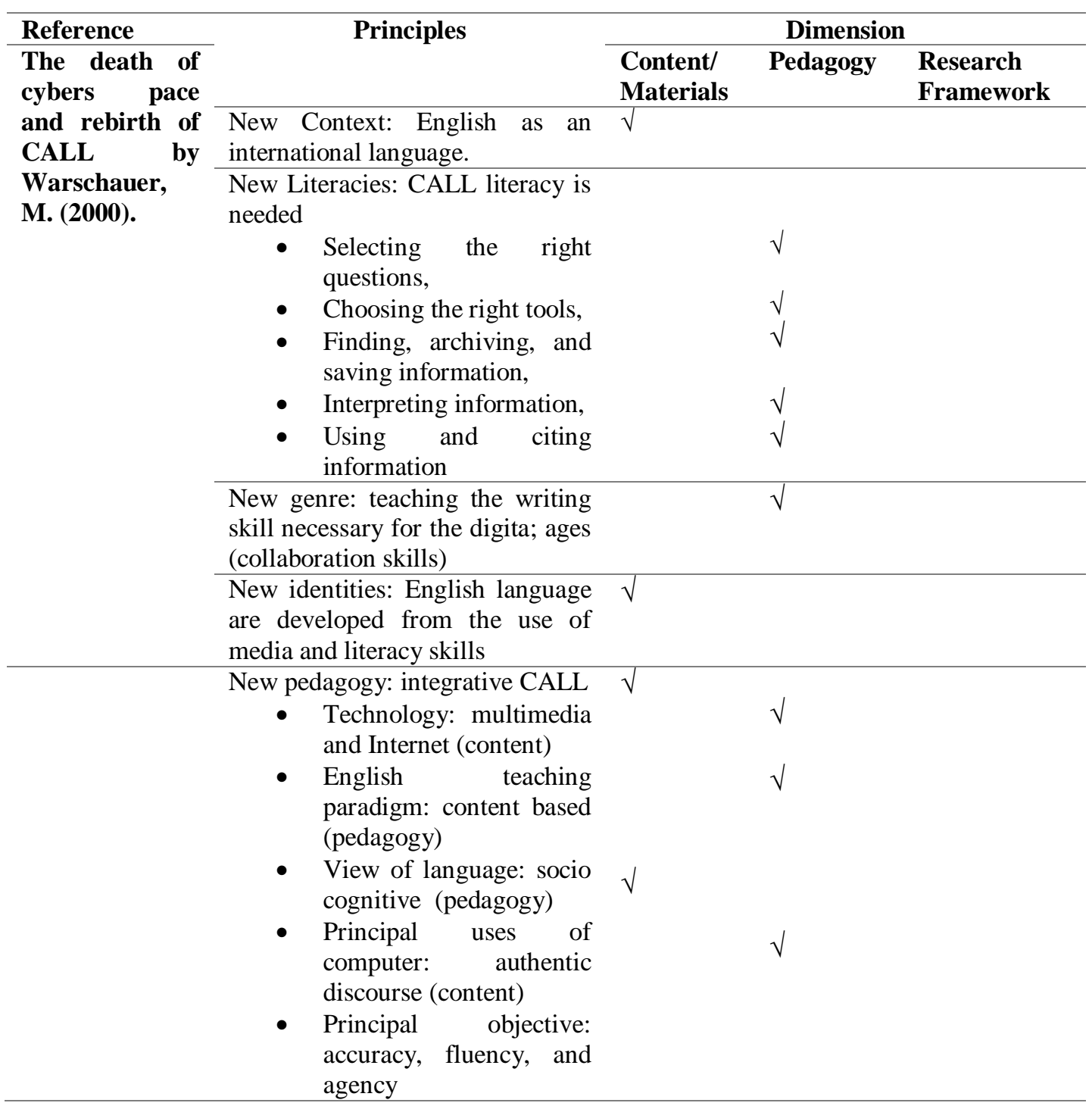

Clustering process may also alleviate the synthesizing process of unifying the separates elements from each individual studies, to produce a coherent argument, theory, and conclusion (Pope, 2017, as cited in Efron, \& Ravid, 2019, p. 177). In addition, the researcher used code as the way to locate the review to the data. Arguably, coding refers to the process of labeling the data using broad category names that could identify and describe the data related to the phenomena (Lodico, Spaulding, \& Voegtle, 2006, p. 
305). Data coding was added to maintain the confidentiality of the identity of research and practice reviewed. The researcher set code by using-Datum. However, the research and practice reviewed identity is known by the researcher and supervisors.

Table 5. Codes of research and practice

\begin{tabular}{lll}
\hline No. & Code & Name \\
\hline 1. & Datum1 & Journal 1 \\
\hline $\mathbf{2 .}$ & Datum2 & Journal 2 \\
\hline 3. & Datum3 & Journal 3 \\
\hline 4. & Datum\#1 & Thesis 1 \\
\hline $\mathbf{5 .}$ & Datum\#2 & Thesis 2
\end{tabular}

A new code was also added in order to locate the position where the research and practice have stated the idea. Before adding a new code, the researcher refers to shapes of the research which are usually used as a form of the research. In regard to this, Paltridge and Starfield propose that abstract, background, methodology, results, discussions, and conclusions, are the structure of research (2007, p. 66). Therefore, the researcher used these structures as a foundation for making a new code.

\begin{tabular}{|c|c|c|}
\hline No. & Code & Name \\
\hline 1. & Abst & Abstract \\
\hline 2. & Int & Introduction \\
\hline 3. & Meth & Methodology \\
\hline 4. & Res & Result \\
\hline 5. & Discs & Discussion \\
\hline 6. & Concl & Conclusion \\
\hline
\end{tabular}

Thematic analysis was undertaken in the research. In this case, thematic analysis was used for analyzing the content of the articles (Brauke, \& Clarke, 2006, as cited in Kirkwood \& Price, 2014, p. 11). Each article and thesis was read several times in order to find out and understand what has been taught by the researchers and teachers regarding CALL in the $21^{\text {st }}$ century.

The structure of a literature review offers a body of review; introduction, main body, and conclusion of the literature review. Cronin, Ryan, and Coughlan (2008) describe the structure of the review: First, The introduction should include a brief overview of the "problem." Second, the main body of the report presents and discusses the findings from the literature. Third, the review should conclude with a concise summary of the findings that describes current knowledge and offer a rationale for 
conducting future research (p. 41). In addition, the researcher identified several principles with a brief description. These form the basis of the reporting structure in the finding and discussion section.

\section{CONCLUSION}

Critical literature review can be a very potential method of research in order to develop new perspectives for ELT research field. Despite the fact that it is not considered as a research method, critical literature review is indeed research, involving data collection and data analysis, which are core of research. Caution should be made in selecting relevant literature, with very possibility of crossing as much as different fields to form interdisciplinary studies. Further studies can be addressed to the potential use of critical literature review in finding new ways for activation of ELT learning or improving the teaching by looking at different fields as insight and see what the review can offer.

\section{REFERENCES}

Alcock, M. (2016, February/March). The future of education: Are we ready?. The Journal of Adventist Education, 52-54.

Al-Emran, M., Mezhuyev, V., \& Kamaludin, A. (2018). Technology Acceptance Model in M-learning context: A systematic review. Computers and Education, 125, 389-412. https://doi.org/10.1016/j.compedu.2018.06.008

Barrot, J. S. (2018). English curriculum reform in the Philippines: Issues and challenges from a 21st century learning perspective. Journal of Language, Identity \& Education, 1-16. https://doi.org/10.1080/15348458.2018.1528547

Campbell, C. (2016, February/March). An unchanging mission in a changing world. The Journal of Adventist Education, 3, 55.

Carnwell, R., \& Daly, W. (2001). Strategies for the construction of a critical review of the literature. Nurse Education in Practice, 1(2), 57-63. https://doi.org/10.1054/nepr.2001.0008

Chapelle, C. A. (2003). English language learning and technology. Amsterdam: John Benjamins Publishing Company.

Cronin, P., Ryan, F., \& Coughlan, M. (2008). Undertaking a Literature Review: A Step by Step Approach. British Journal of Nursing, 17(1), 38-43.

Efron, S. E. \& Ravid, R. (2019). Writing the literature review: A practical guide. New York: The Guilford Press

Elmer E. Rasmuson Library. (n.d.). Library Research Process. Retrieved December, 27, 2019, from https://library.uaf.edu/ls101-research-process

England, S. (2016, February/March). Critical thinking and inquiry in adventist education. The Journal of Adventist Education, 4-10. 
Galvan, J. S. (2017). Writing literature review: A guide for students of the social and behavioral sciences. Los Angeles: Routlede Taylor and Francis Group.

Gheondea-Eladi, A. 2015. Conducting critical literature reviews: a methodological note, Calitatea Vietii, 26(2), 167-190.

Grewal, A., Kataria, H., \& Ira, D. (2016). Literature search for research planning and identification of research problems, (27), 27-31. https://doi.org/10.4103/0019-5049.190618

Jesson, J. K., Matheson, L., \& Lacey, F. M. (2011). Doing Your Literature Review: Traditional and Systematic Techniques. London: Sage

Jesson, J., \& Lacey, F. (2006). How to do (or not to do) a critical literature review. Pharmacy Education, 6(2), 139-148. https://doi.org/10.1080/15602210600616218

Kirkwood, A., \& Price, L. (2014). Technology-enhanced learning and teaching in higher education: what is "enhanced" and how do we know? A critical literature review. Learning, Media and Technology, 39(1), 6-36. https://doi.org/10.1080/17439884.2013.770404

Lian, A-P. (2017). The inexorable rise of the proletarian autodidact. In A. Lian, P. Kell, P. Black, \& K. Y. Lie (Eds.), Challenges in global learning: Dealing with education issues from an international perspective (pp. 282-313). Newcastle upon Tyne: Cambridge Scholars Publishing.

Lian, A., Bordnarchuk, A., Lian, A, \& Napiza, C. (2017). Academic writing as aesthetics applied: Creative use of technology to support multisensory learning. In In A. Lian, P. Kell, P. Black, \& K. Y. Lie (Eds.), Challenges in global learning: Dealing with education issues from an international perspective (pp. 350-374). Newcastle upon Tyne: Cambridge Scholars Publishing.

Lian, A. (2019). What axioms informs your research? Dialogizining for innovation in English language and literacy pedagogy. Education and Humanities Research, (394), 440-448.

Lian, A. B., \& Pertiwi, W. H. S. (2017). Theorising for innovation: Implications for English language teacher education. GEMA Online Journal of Language Studies, 17(3), 1-17. https://doi.org/10.17576/gema-2017-1703-01

Lodico, M. G., Spaulding, D. T., \& Voegtle, K. H. (2006). Methods in Educational Research: From Theory to Practice. San Francisco, CA: Jossey-Bass Wiley.

Mahmood, K. (2017). Systematic Literature Review. Retrieved May 21, 2020, from https://www.slideshare.net/kmahmood2/systematic-review-73173308

Mustaqimah, H. A. (2020). Bridging the gap between theory and practice of CALL: A critical literature review (Unpublished undergraduate thesis). IAIN Syekh Nurjati Cirebon, Indonesia.

Nashruddin, W. (2019). Integrating undergraduate research and inquiry in English language teacher education programs in Indonesia: A case study (Unpublished doctoral thesis). Charles Darwin University, Australia.

Paltridge, B., \&Starfield, S. (2007). Thesis and dissertation writing in a second language: A handbook for supervisors. London: Routledge

Southern Cross University. (2020). EDU00751 - Critical Literature Review (2020). Retrieved 13 October 2020 from https://www.scu.edu.au/study-atscu/units/edu00751/ 
Suiter, A., M., \& Sarli, C., C. (2019). Selecting a journal for publication: Criteria to consider. The Journal of Missouri State Medical Association, 116(6), 461-465. Retrieved from https://www.ncbi.nlm.nih.gov/pmc/articles/PMC6913840/\#: :text=Transparen cy\%20from\%20the\%20journal\%20as, quality\%20journals\%20suitable\%20for $\% 20$ publication.

Warschauer, M. (2000). The death of cyberspace and rebirth of CALL. English Teachers' Journal, 53, 61-67. 